\title{
The Narrative Assemblage of Civil Society Interventions into Refugee and Asylum Policy Debates in the United Kingdom
}

\author{
Katherine Tonkisss
}

\section{Introduction}

Influencing policy is a key area of activity for civil society organisations (CSOs) with a campaigning remit (Marquez, 2016; Phillips, 2006; Taylor, 2003). However, often such CSOs find themselves in 'adversarial' relationships with policymakers as a result of highly divergent understandings of policy problems and their potential solutions (Najan, 2003). CSOs in such adversarial positions discursively construct alternatives to the dominant policy position (cf. Pauly et al., 2016), but might find themselves on the periphery of the debate as they lack any convergence of interests or ideas with policymakers. Under such circumstances, 'making a lot of noise' in the debate may not be an effective enough strategy to garner influence over policy (Bates and Pitkeathley, 1996: 86).

This article seeks to examine how CSOs discursively navigate the challenges of seeking to influence policy under these kinds of adversarial conditions. To do so, it focuses on the work of domestic CSOs engaging with policy debates about refugee and asylum rights in the United Kingdom. This is a particularly useful example because previous studies have found that these organisations face significant challenges in navigating policy debates which are largely hostile to their views (Cook, 2010; Cullen, 2009; McGhee et al., 2016; Somerville and Wallace Goodman, 2010; Statham and Geddes, 2006).The article presents an analysis of research into the 'policy narratives' of seven case study organisations working in the UK to explore how these challenges shape the organisations' interventions into policy debates in the UK field and, consequently, how they position themselves as policy actors.

The article argues that the organisations discursively navigate the challenges they face when intervening in policy debates by operationalising a narrative 'assemblage'. Assemblage theory (cf. Deleuze and Guttari, 1987) is concerned with capturing the complexity of the social world, and in policy studies is used to examine the dominant and counter-hegemonic assemblages of diverse ideas and practise which comprise policy fields (Newman and Clarke, 2009). The article shows that the narrative assemblage operationalised by the organisations is comprised of distinct but interweaving narratives which both conform to and contest the dominant construction of refugee and asylum policy problems and their potential solutions. Within this assemblage the organisations are positioned as both policy experts in their own right and as facilitators of the first-hand knowledge of refugees themselves. It is through this assemblage that the organisations maintain their presence and voice in a largely hostile policy context while at the same time seeking to disrupt the parameters of key debates. As such, the paper delivers critical new empirical insights concerning how CSOs work to position themselves to influence policy under adversarial conditions.

Refugee and asylum civil society: the 'ideological gulf' and the 'advocate's dilemma' 
CSOs seeking the realisation of refugee and asylum rights in national and international settings are situated at once within particular states and as part of a wider movement for the rights of different kinds of migrants. This movement is composed of a variety of groups including grassroots activists, United Nations agencies and academic institutions, among others. While some organisations are international in scope, such as the International Network on Migration and Development and Migrants Rights International, i this article focuses on those which could be defined as 'domestic' or active within particular states, though they may engage in international cooperation with other relevant groups (see also Cullen, 2009). These organisations also contrast with grassroots activism as they are not protests led by migrants and refugees campaigning for their own rights or individual volunteers engaging in direct action, but organisations staffed predominantly by citizens and resident noncitizens seeking to advocate for the rights of others (see also Espadas et al., 2012; Lentin and Moreo, 2012; Monforte, 2016).

Alongside leading public protests, engaging in legal advocacy and providing hands-on support (cf. de Graauw, 2016; Garkisch et al., 2017), these organisations regularly engage with national level policy debates about various issues related to human mobility. Notable works have exposed the marginalisation of these CSOs in policy debates due to a lack of capacity, resources, and support from other interest groups (Somerville and Wallace Goodman, 2010; Statham and Geddes, 2006).

Beyond these material factors, two further critical dynamics affecting these organisations are particularly relevant to understanding the challenges which may arise for these CSOs, relating to their adversarial positioning in policy debates. The first of these is what I will refer to, following Somerville and Wallace Goodman (2016: 966) as the 'ideological gulf'. Somerville and Wallace Goodman identify a problematic division between government and civil society in their study of the refugee and asylum policy debate, not just over how to design policy appropriately but also regarding the very nature of the policy problem itself. They argue that this ideological gulf explains why civil society lacks relative influence over policy in contexts characterised by high levels of anti-immigration sentiment and limited appetite for the recognition of noncitizen rights. We know less, however, about how this gulf shapes the ways in which CSOs intervene in policy debates. How do the CSOs discursively navigate the challenges of engaging in policy debates which are largely hostile to their aims?

The second critical dynamic is the 'advocate's dilemma'. In her 2010 article on migration rights advocacy in the United States, Maria Lorena Cook conceptualises the dilemma as follows:

...on the one hand, universal norms such as human rights, which are theoretically well suited to advancing immigrants' claims, may have little resonance within national settings; other the other hand, the debates around which immigration arguments typically turn, and the terrain on which advocates must fight, derive their values and assumptions from a nation-state framework that is self-limiting (Cook, 2010: 146)

The dilemma for the CSOs considered in this article is that on the one hand, framing the rights of refugees and asylum seekers in terms of human rights is most appropriate to 
their aims but this framing can often lack relevance to the context in which they are active and therefore limit their impact. As a result, they may choose to strategically frame their work in relation to the particular national context in which they work in order to enhance their potential impact (see also Kim, 2009). But on the other hand, if protests and campaigns are grounded within the national context, this in itself can limit the claims that the activists are able to present because the scope of justice and rights is automatically framed in terms of the national policy context and not in terms of universal human rights

While work on this dilemma has focused on advocacy and activism, we know less about how the advocate's dilemma shapes the policy work of CSOs. How do these organisations negotiate tensions in their positioning between the national and the global when they engage in policy debates?

\section{Context of the research}

Case study research was undertaken to address the questions identified in the preceding section:

1. How do pro-refugee and asylum CSOs discursively navigate the challenges of engaging in national policy debates which are largely hostile to their aims?

2. How do these organisations negotiate tensions in their positioning between the national and the global when they engage in these debates?

The refugee and asylum policy context of the UK is well-suited to examining how CSOs engage with policy debates which are largely opposed to their perspective. Previous research has identified a key dividing line in British immigration politics between a more restrictionist state on the one hand and an expansionist civil society on the other ${ }^{i i}$ (Gray and Statham, 2005). While civil society policy influence has tended to be limited in contrast to other actors (Somerville and Wallace Goodman, 2010), national level CSOs have tended to have the greatest degree of civil society influence with the 800 or more local community-based refugee organisations and other networks of local organisations engaging far less regularly with policy and having far less influence (Somerville, 2007; Zetter and Pearl, 2000). They also operate alongside large multinational charities with presence in the field of refugee and asylum, such as Oxfam and Amnesty International, although these are excluded from the present study as the focus is on national organisations.

There was relatively little policy interest in refugee and asylum policy in the UK until the late 1980s, when the number of refugees seeking sanctuary in the UK began to increase and politicians became concerned with stemming this flow. As a result, the arrival of increasing numbers of refugees began to be treated as a matter of immigration control rather than humanitarian crisis, and policy was directed at reducing the number of refugees (Kaye, 1994). This focus continued into the 1990s and under subsequent New Labour governments, with the language of government and the media serving to construct a strongly negative portrayal of refugees (Mulvey, 2010). A central strategy was to narrow the category of the 'deserving' refugee to those recognised under UN conventions rather than 'spontaneous' refugees arriving in the UK by other means. Policy 
changes in the late 1990s thus constructed the category of 'asylum seeker' as an 'undeserving' category of potential refugees often presumed to be 'bogus' and criminalised through the use of detention (Sales, 2002). Underpinning this policy was a logic that asylum seekers were drawn to the UK because it was too attractive a destination, rather than for genuinely humanitarian reasons. As a result, policies of mandatory dispersal were implemented to share the 'burden' of asylum seekers across the country, asylum seekers were not permitted to work or claim associated social security benefits, and the amount of specific financial support available to asylum seekers was reduced to a level far below that of existing citizens claiming social security benefits in an attempt to dissuade them from making the journey (Bloch, 2009). This policy approach has continued throughout the first two decades of the $21^{\text {st }}$ century, with policymakers, despite much evidence to the contrary, heavily influenced by the idea that asylum seekers could be discouraged from travelling to the UK by making it a less attractive destination (Mayblin, 2016).

Most recently, the escalation of armed conflict in Syria has once again raised the profile of refugees and asylum seekers in British policy debates. In 2016 it was estimated that $50 \%$ of the Syrian population had been displaced by the conflict (Amnesty International, 2016). While only a very small percentage of Syrian refugees were offered resettlement in Europe or reached the continent by other means, many thousands died attempting to cross the Mediterranean Sea to reach safety in a European country - 2,500 deaths in the first five months of 2016 alone (UNHCR, 2016). The policy response of the UK Conservative governments (2015-) mirrored earlier approaches, with a focus on limiting the number of refugees able to settle in the UK. Those permitted to settle were primarily drawn directly from the region ${ }^{\mathrm{iii}}$ as recognised refugees. This meant that many thousands of others attempting to enter the country by other means remained stranded at refugee camps in northern France. The dominant narrative constructed those arrivals as less deserving than those resettled directly from the region, and more likely to be economic migrants than genuinely in humanitarian need (cf. Buncome, 2016). This, again, suggests the persistence of the logic of the 'pull factor' and the construction of asylum seekers as less deserving than refugees granted entry under resettlement programmes.

\section{Method}

The research focused on the interventions into these policy debates of seven case study organisations in the UK, as summarised in Table 1. While focusing on a smaller number of organisations cannot provide insights across the entire sector, a case study design enabled a focus on a selection of representative CSOs in greater detail than would be permitted by a longitudinal study. The organisations were sampled purposively from a mapping exercise which identified all national level pro-migrant CSOs in the UK and then filtered this population to identify those organisations that had a remit a) to work on refugee and asylum issues and $b$ ) to engage with national policy. This produced a total of 21 organisations, and a sample of one third of these comprised the case studies. These seven were selected to represent the diversity of sizes of CSOs present in the overall population. 
Given the scope of the study it was only possible to include organisations operating at a national level, and so local level organisations were not included and neither were organisations operating solely within the devolved administrations of the United Kingdom. While focusing solely on national level organisations reduced the scope of the article to consider other forms of CSO with national policy influence in the UK, this also allowed for uniformity in the type of organisation being examined.

\section{$<<$ TABLE 1 AROUND HERE $>>$}

A dataset was collated, comprising 363 documents collected between May 2015 and May 2016, a period covering significant debates over refugees and asylum policy in the UK, in particular relating to Syrian refugees, and so offering a fruitful opportunity to analyse the narratives of the organisations at a key moment of discursive contestation. From initial searches of the websites of the organisations, key types of documents to be included in the dataset were identified. These were publicly available documents most likely to contain expressions of policy narratives, and comprised policy reports, briefings and press releases prepared by the organisations, newspaper articles featuring first-hand quotes from representatives of the organisations, policy inquiries (including both written and oral evidence) featuring the organisations, and mentions in parliamentary contexts gathered from Hansard records. A summary of the dataset is provided in Table 2. It also included the mission statements and most recent annual report for each organisation available on their websites to provide a sense of the overall purpose of policy engagement.

\section{$<<$ TABLE 2 AROUND HERE $>>$}

A policy narrative analysis approach was implemented to analyse the documents. Policy narrative analysis offered a useful tool with which to explore the ways in which the CSOs engaged discursively with policy debates. Narrative analysis has a long history in the social sciences (e.g. Foucault, 2002; Ricoeur, 1984), and policy narrative analysis is increasingly seen as a particularly valuable approach to studying different kinds of migration policy debates, where diverse perspectives compete for space (cf. Boswell, 2011). Policy narratives are understood as a medium of contestation over the definition of policy problems. They are 'a primary means through which individuals organise, process, and convey information' (Jones and McBeth, 2010: 300). The choices that actors make about what to include in these narratives matter to the way in which they ultimately construct their interpretation of the policy problem and its solution (Hajer, 1993).

Policy narratives coalesce into discursive battles over what constitutes the public good for different actors positioned within a subjective political reality (Stone, 2002). These battles are drawn between a dominant narrative with hegemonic status and alternative ways of viewing the policy problem and its solution (Hajer, 1993; Roe, 1994). Narratives do not therefore simply convey information but rather exist as arguments in favour of a certain course of action. Policy narrative analysis involves the identification of these storylines within a given text or series of texts.

In order to conduct the analysis, the texts were subjected to an inductive analysis whereby narratives were identified and coded for common themes (using nVivo) arising 
from the texts themselves, rather than from a pre-determined coding framework, in order that the analysis captured as wide a range of narratives as possible. Inevitably because the research design focused on case study organisations in the UK, the narratives themselves relate to specific national policy debates and thus have a distinctly national character. However, focusing in on this specific policymaking arena enabled a greater degree of detail in the narrative analysis than a more comparative research design, as set out below.

\section{Between conformity and contestation}

This section presents the analysis of the data in response to the two research questions posed. Firstly, the section focuses on how the organisations navigate the 'ideological gulf' in their policy work. As would be expected, there is significant evidence in the data of an ideological gulf between the organisations and dominant policy agendas. This is reflected specifically in the ways in which the policy narratives of the organisations contest these agendas.

Given the noted timing of the data collection, a large proportion of this contestation concerned Syrian refugees. The data reveals how the organisations sought to contest the idea that their plight was an external 'crisis' facing Europe, and how they attempted to shift the meaning of the crisis to one of policy failure rather than of a crisis in and of itself. For example, the Refugee Council noted in a submission to the House of Lords, '[i]n their effort to tackle irregular migration, the UK and other states have placed a plethora of controls overseas that effectively prevent refugees... as well as irregular migrants from reaching our shores' (Refugee Council, 2015a). In the accompanying media coverage, they also noted how 'European leaders have failed to acknowledge the humanitarian tragedy unfolding in the Mediterranean is of their own making' (quoted in Grice, 2015). In both of these excerpts, the emphasis is placed on how policymakers have created a crisis at the borders of Europe through the implementation of policy. This is a counter-narrative to the wider dominant narrative present in the media and amongst mainstream politicians at the time which conveyed the idea that refugees themselves were the problem, and that 'floods' and 'swarms' of refugees were overwhelming European countries (Shariatmadari, 2015). The counter-narrative is particularly evident in this quote from the Migrants' Rights Network:

This is the real reason why we have a refugee crisis in Europe today driven not so much by the movement of people as the failure of politicians and political systems... the so-called refugee crisis in Europe today is in reality more a crisis of policy than of people. (Flynn, 2016)

A similar construction of the policy problem also appears in the data with regards to asylum policy, where the dominant representation of asylum seekers as 'bogus' and 'failed' is challenged through the argument that it is existing policy which has failed:

The asylum system denies many in need of protection, and in our opinion, does so deliberately. Official terminology for someone refused asylum is a 
'failed asylum seeker', but if it is the system that has failed, then who is genuine? (Right to Remain, 2015)

Here, again, the narrative serves to subvert the focus of crisis and failure away from individual refugees and asylum seekers and towards policymakers designing inadequate policy.

The ideological gulf was also apparent in narratives which focused on re-humanising refugees and asylum seekers. For example, the Joint Council for the Welfare of Immigrants noted that '[w]hen speaking about refugees and migrants, we must remember first and foremost that we are talking about people. Reducing the humanity of others is incredibly dangerous' (Joint Council for the Welfare of Immigrants, 2015a). This strategy of shifting the language from 'refugees' to 'people' was particularly prominent in the data. For example, the Migrants' Rights Network noted that:

We've been trying to build high fences and have heavy policing for 15 years and the most it accomplishes is a short break in the cycle. People are now dying on a regular basis. (quoted in Elgot and Taylor, 2015)

The subtle shift in language contrasts with much of the mainstream media coverage and political rhetoric which used the term 'migrant' to refer to refugees and often also used dehumanising language, as well as the language of illegality, to describe refugees and asylum seekers (Taylor, 2015). The Refugee Council directly challenged then Prime Minister David Cameron's dehumanising language, commenting that '[i]t's extremely disappointing to hear the prime minister using such irresponsible, dehumanising language to describe the desperate men, women and children fleeing for their lives' (quoted in Troup Buchanan, 2015), and the Migrants' Rights Network urged the government to '...put together a task force which can engage with the people in Calais on terms which acknowledge the humanitarian root cause of the problem' (quoted in Morris, 2015).

Together with the contestation that we would expected to see as a consequence of the ideological gulf there is also, however, evidence in the dataset of conformity to some of the dominant features of the policy debate about refugees and asylum seekers. Specifically, the narratives often reproduced perceptions of migrant deservingness which posit refugees as a humanitarian exception, more deserving than other kinds of migrants (Andreouli and Dahtipour, 2014). For example, the following quote is illustrative of this narrative form: ' $[\mathrm{t}]$ he government should not let its obsession with controlling immigration override its legal and moral responsibility to protect refugees' (Refugee Council, 2016). In the quote, refugees are separated from wider issues concerning the control of mobility. While the narrative serves to contest government policy concerning the rights of refugees, it treats this as a separate matter to wider issues of immigration control and does not contest the construction of exclusionary regimes of membership per se.

The main way in which this humanitarian exceptionalism was displayed in the dataset was concerned with reinforcing the vulnerability and victimhood of refugees. In many 
cases this involved drawing attention to particularly vulnerable groups of refugees, as in the following quote:

...our clients have included women in their 60 s, families and young children, men and women with disabilities or major health problems or suffering the effects of torture. (Singer, 2015)

This narrative contests the mainstream narratives at the time which posited that many of those arriving from Syria were healthy young men seeking opportunities for economic advancement rather than 'genuine' refugees (Clark, 2015Yet while the aim of this counter-narrative is to subvert these kinds of assumptions by arguing that the refugees are more 'needy' than the dominant narrative suggests, by highlighting that refugees are particularly needy the narrative also serves to reproduce dominant tropes about deserving and undeserving categories of migrants, and also that some refugees are more deserving than others depending upon their observable vulnerability. A similar framing is found in this quote from Right to Remain: '[e]veryone, but especially children and vulnerable young people, should have equal access to the law, no matter their country of origin' (Right to Remain, 2015b). Here the use of 'especially' defines a special category of deservingness based on vulnerability.

Many of the narratives focused on the victimhood of the refugees. For example, the Refugee Council noted:

It is absolutely horrific to think that instead of being a welcoming place of safety for people who've been tortured and raped, Britain is actually a place where these victims are treated like criminals and thrown behind bars. (quoted in Troup Buchanan, 2015)

This focus on victimhood is also played out later in the dataset, such as in the following: 'Ministers appear happy to stand on the side lines and watch on passively while refugee mothers run out of milk for their babies and are forced to resort to washing them in puddles' (Refugee Council, 2016). The focus on victimhood in turn reinforces the dominant narrative of humanitarian exceptionalism which views some refugees as more deserving than those with other kinds of legal statuses and some refugees as more deserving than others (e.g. Cohen, 2016; cf. Sales, 2002). When the Joint Council for the Welfare of Immigrants stated '[m] any will have fled persecution, war, destruction and displacement, and have valid claims for asylum' (quoted in Segalov, 2015) they implicitly accept the definition of deservingness or otherwise of human mobility in humanitarian terms and accept the validity of such judgments of deservingness in border control. That is not to suggest that the organisations are wrong to draw attention to particularly desperate situations or to particular hot spots in the policy debate. However, it does illustrate that in seeking to narrow the ideological gulf they may reproduce, in part, the construction of the policy problem that they seek to contest. While there is a strong ideological gulf in terms of policy solutions, this gulf is as such somewhat narrower with respect to how the policy problem is constructed according to issues of deservingness, victimhood and vulnerability - key features of the national policy debate itself. 
Moving now to the second research question concerning how the organisations negotiate the 'advocate's dilemma', this co-existence of conformity and contestation is once again evident. Further narrative conformity was found in the dataset in the form of 'discursive affinity' (Hajer, 1993) with wider mainstream policy narratives beyond the specifics of the refugee and asylum policy field. This offers some insights into how the organisations grounded the global scale of the rights and protections they sought to realise within national level policy contexts. For example, many of the narratives focused on the weaknesses in legal representation for asylum cases, and grounded an argument for asylum rights in widely held norms concerning the right to fair trial: '[m]any people are forced to navigate the asylum system with no legal representation, due to the savage legal aid cuts imposed over the years' (Right to Remain, 2015a). Here a wider campaign for better access to legal aid for the general (citizen) population (see also Bowcott, 2015) is used to make an argument for fair trial for (noncitizen) asylum seekers. This narrative was also found in the Asylum Aid data: '...through Legal Aid, Britain recognises that even - and especially - the poorest and most vulnerable must have access to the justice system' (Asylum Aid, 2015). These narratives subvert the definition between citizens and noncitizens in access to fair trial, and in doing so they ground a claim for a universal right in terms of a specific national policy debate.

A further example of the presence of this discursive affinity with national policy debates is found in narratives which play into widely accepted norms associated with family values. For example, the Refugee Council argue that ' $[t]$ he Government is so keen to appear tough it's now viciously targeting vulnerable families and appears determined to take away people's ability to feed, clothe and house their children' (Refugee Council, $2015 b)$. In this quote we see a focus on the language of 'people' as well as on vulnerability, as discussed previously, alongside norms about the deservingness of children and families which are drawn on to convey unfairness in the government's treatment of refugee and asylum seeking children and families.

The organisations commonly drew on the government's own data in their narratives, and this appears in the dataset as another means of grounding the global within the specifics of the national. Indeed, it could also be seen as another means of cultivating conformity because it enables the organisations to conform to the terms of the policy debate while also contesting it (see also McGhee et al., 2016). For example, Right to Remain drew on Home Office data concerning the legal representation of asylum seekers to put forward a re-interpretation of the government's own data:

Over $25 \%$ of Home Office asylum refusals are overturned on appeal... Most of those overturned decisions are when people have managed to find a good lawyer to represent them. (Right to Remain, 2015a)

Similarly, the Refugee Council used Home Office data to contest the narrative of then Home Secretary Theresa May on refugees:

She also failed to mention that $34 \%$ of those crossing are Syrians. According to the latest Home Office statistics, 85\% of Eritreans and Syrians claiming asylum in the UK were recognised as refugees. (Refugee Council, 2015a) 
While the analysis suggests that discursive conformity enabled these organisations to negotiate the advocate's dilemma by grounding the global within the language of the local, the narratives also position the CSOs as policy experts beyond the confines of the specific national policy context. For example, many of the narratives drew on international comparisons to introduce new knowledge and policy options into the debate:

The UK is unique in Europe in having no time limit and routinely detaining migrants for years... France limits detention to a maximum of 45 days, yet nevertheless enforces $31 \%$ more removals of irregular migrants and asylum seekers than the UK. (Detention Action, 2014)

Similarly, the Refugee Council uses its international expertise to present evidence from Brazil and France concerning the use of humanitarian visa programmes to resettle refugees (Refugee Council, 2015d). The use of such examples introduces policy options to the debate from beyond the specific national context and thus alters the parameters of what is seen as a viable policy option.

Furthermore, many of the narratives transform the parameters of heard and silenced voices within the policy debate beyond their traditional national-citizen limits. Here, the CSOs are positioned not as experts directly but rather as facilitators of the expertise of refugees themselves. Many of their mission statements showed a central focus on promoting first-hand voices, as Detention Action state '[w]e challenge stereotypes and ensure that people in immigration detention centres are not invisible and unheard' (Detention Action, 2016), and the Migrants' Rights Network note '[w]e particularly forefront the concerns of migrant groups creating space for them to voice their views and experiences' (Migrants' Rights Network, 2016).

Given their unique positioning within the national policy debate but also working radically outside of it, the organisations draw on the qualitative testimony of refugees themselves in their policy narratives. For example, the Refugee Council presented 'Rauf's story' on their blog, which is told in Rauf's own words, to convey the experience of detention and to show why detention policy is problematic (Refugee Council, 2015c. The data for Women for Refugee Women includes a high proportion of first-hand testimony from refugees and asylum seekers, for example including June's story, a detainee describing her experiences of detention, and Priya's story which is used in a policy briefing to contest the detention of pregnant women:

It was too far for my partner to visit and, as an asylum seeker as well, he couldn't afford to travel, but we spoke on the phone every day. I've been released now but I still feel depressed, like everything is over. I don't understand why I was treated like that. (Women for Refugee Women, 2016)

The emotive structuring, in contrast to the quantitative narratives outlined above, should not disguise that this is expertise in the form of first-hand testimony. Narratives are constructed as much from what is said as from what is selected to be silenced. In refusing, at least in part, to perpetuate the silencing of noncitizen voices in these policy debates, the organisations transform the nationally defined contours of inclusion, exclusion and 
political participation (see also Monforte, 2016) while retaining ultimate control over the forum in which these voices are heard as a consequence of their positioning between the national and the global.

\section{Narrative assemblage}

This discussion of the findings shows the complex ways in which narratives of conformity and contestation are weaved together. While the organisations engage first and foremost in contesting policy, they also engage in some conformity to dominant ideas about deservingness and norms associated with civil liberties and family values. They also simultaneously position themselves as policy experts in their own right and as facilitators of the expert first-hand knowledge of refugees.

What do these findings mean for the research questions posed earlier in the article? Firstly, while as expected the ideological gulf is strongly evident in the ways in which the organisations contest policy, there is also evidence of strategies to construct arguments for the rights of refugees and asylum seekers which have affinity with dominant policy discourses. This is suggestive of attempts to navigate the challenges which arise from engaging in policy debates which are largely hostile to the aims of these organisations, by framing arguments in the dominant language of those debates. Secondly, the organisations appear to negotiate tensions in their positioning between the national and the global through this conformity and also by utilising their unique positioning both to deliver policy expertise and to open up spaces for the first-hand testimony of refugees.

Assemblage theory offers a useful means of conceptualising this coexistence of multiple, overlapping and sometimes slightly contradictory narratives. In the seminal work of Deleuze and Guttari (1987), assemblage denotes a means of capturing the complexity of the social world and subverting the strict division of structure and agency. Translated into the field of policy analysis, assemblage theorists conceive of policy as 'an assemblage of texts, actors, agencies, institutions and networks' (Prince, 2010: 173), with singular assemblages constructing policy through 'a pragmatic compilation of a diverse set of ideas and conditions'. These assemblages themselves exist as components of wider complex assemblages of governance (Rizvi and Lingard, 2011: 8). Policy fields are constituted from dominant and counter-hegemonic assemblages, and these are 'articulated' through discursive practices as a coherent whole (Newman and Clarke, 2009; Sharma, 2008).

The organisations featured in this article construct a refugee and asylum rights assemblage through which they practice their policy role and through which they manage challenges and tensions in that role. The assemblage, set out in Table 3 , is made up of a diversity of policy narratives which are distinct from one another but which also weave into each other in complex ways, drawing on ideas which both contest and conform to the dominant narratives of the refugee and asylum policy field. It is also made up of different modes of expressing expertise, and it includes the different ways that the CSOs are positioned, both as policy experts in their own right and as facilitators of the expert knowledge of refugees. 
This strategic assemblage of narratives, modes and positionings is the result of the ways in which CSOs navigate the challenges associated with intervening into policy debates within which the majority of actors are hostile to their position. It is also the result of the ways in which the organisations negotiate tensions implicit in their positioning, both operating within the existing policy and institutional framework and seeking to reach beyond it through the radical overhaul of border regimes.

These organisations tread a fine line between protesting the injustices that they perceive in refugee and asylum policy, and partially reproducing the assumptions underpinning that policy. Understanding the policy role of these CSOs through the language of assemblage captures the ways in which these tensions are managed rather than settled, and endure to shape policy engagement. Indeed, as Newman and Clarke (2009) note, organisational assemblages are constantly in flux as these relationships and practices play out in changing policy contexts.

\section{Conclusion}

This article set out to examine how CSOs discursively navigate the challenges involved in seeking to influence policy under adversarial conditions where they may strongly oppose the dominant policy position in a given domain. To do so, it focused in detail on the work of domestic CSOs engaging with policy debates about refugee and asylum rights in the United Kingdom. In particular, it aimed to better understand how these organisations navigate the 'ideological gulf' between themselves and policymakers, and how they negotiate the 'advocate's dilemma' when they seek to ground the global scope of their work in the national policy contexts in which they are active.

Focusing on the policy narratives of seven case study CSOs in the United Kingdom, the article showed how these organisations weave together narratives of conformity and contestation when they engage in policy debates. For the ideological gulf, the co-existence of conformity and contestation may enable the organisations to gain voice in the debate by speaking according to some of its main assumptions concerning the policy problem while contesting it in other ways. For the advocate's dilemma, the weaving together of these narratives is a consequence of how the organisations seek to speak about global concerns through the language of the national policy context. Rather than finding a resolution, therefore, the advocate's dilemma appears as a productive tension shaping the policy work of the organisations.

As such, the article has delivered insights into how CSOs navigate the challenges of seeking to influence policy under adversarial conditions, and the dilemmas they face in doing so. The research highlights the importance of narrative strategies for developing a kind of 'proactive co-option', whereby organisations discursively mirror dominant traits of the debate in order to overcome some of the marginalisation resulting from their adversarial positioning. Further research could build on these findings to map the success of such strategies, and across other policy areas. The article also demonstrated the utility of policy narrative analysis, and in particular the concept of assemblage, for making sense 
of this policy work. Assemblage theory was employed to build a picture of how, in the case studies, a patchwork of narratives, modes and positionings co-existed to facilitate engagement with policy debates. Assemblage captures the unsettled nature of the tensions implicit in the positioning of these organisations, and permits a detailed and nuanced approach to modelling the complexities facing CSOs working in often hostile national policy contexts.

\section{Acknowledgments}

I am grateful to the editors and anonymous reviewers of this journal, together with Chris Skelcher, for helpful comments on previous drafts. An earlier version of this paper was presented at the 2016 Interpretive Policy Analysis conference in Hull, UK, and I am grateful to participants on that occasion for insightful comments and discussion.

\section{Funding}

This research was supported by the British Academy (SG142335).

\section{References}

Amnesty International, 2015, Syria's refugee crisis in numbers, Amnesty International, https://www.amnesty.org/en/latest/news/2015/09/syrias-refugee-crisis-innumbers/

Andreoui, E, and Dashtipour, P, 2014, British citizenship and the 'other': an analysis of the earned citizenship discourse, Journal of Community and Applied Psychology, 24, 2, 100 110.Asylum Aid, 2015, Democracy in action: Asylum Aid responds to the Daily Mail, Asylum Aid http://www.asylumaid.org.uk/democracy-in-action-asylum-aid-respondsto-daily-mail//

Basok, T, 2009, Counter-hegemonic human rights discourses and migrant rights activism in the US and Canada, International Journal of Comparative Sociology, 50, 2, 183205.Bates, F, and Pitkeathley, J, 1996, Standing up to be counted: campaigning and voluntary agencies, in Hanvey, C, and Philpot, T, eds., Sweet Charity: The Role and Workings of the Voluntary Sector. London: Routledge.

Betts, A, 2013, Survival Migration: Failed Governance and the Crisis of Displacement, Ithaca, Cornell University Press.

Bloch, A, 2000, A new era or more of the same? Asylum policy in the UK, Journal of Refugee Studies, 13, 1, 29-42.

Bloom, T, 2014, Extended Report: Global Migration Governance: A Decade of Change? Policy Report no. 02/07. Barcelona, United Nations University. 
Boswell, C, Geddes, A, and Scholten, P, 2011, The role of narratives in migration policymaking: a research framework, British Journal of Politics and International Relations, 13, 1, 1-11.

Bowcott, 0, 2015, Criminal barristers stop taking new crown court cases in legal aid protest, Guardian, https://www.theguardian.com/law/2015/jul/27/criminalbarristers-stop-taking-new-crown-court-cases-legal-aid-protest

Buncombe, A, 2016, Theresa May's first speech to the UN General Assembly: read the complete text, Independent, http://www.independent.co.uk/news/uk/politics/theresamays-first-speech-to-the-un-general-assembly-read-the-complete-text-a7319601.html

Clark, R, 2015, We need tougher policies to tackle bogus asylum seekers, Express, http://www.express.co.uk/comment/expresscomment/561412/Ross-Clark-on-bogusasylum-seekers-and-Britain-being-seen-as-a-soft-touch.

Cohen, N, 2016, To help real refugees, be firm with economic migrants, Guardian, https://www.theguardian.com/commentisfree/2016/feb/06/liberals-harsh-truthshelp-refugees-syria

Cook, M.L, 2010, The advocate's dilemma: framing migration rights in national settings, Studies in Social Justice, 4, 2, 145-164.

Cullen, P.P, 2009, Irish pro-migrant nongovernmental organisations and the politics of immigration, Voluntas, 20, 2, 99-128.

De Graauw, E, 2016, Making Immigrant Rights Real: Nonprofits and the Politics of Integration in San Francisco, Ithaca, Cornell University Press.

Deleuze, G, and Guttari, F, 1987, A Thousand Plateaus: Capitalism and Schizophrenia, Minnesota, University of Minnesota Press.

Detention Action, 2016, About us, Detention Action, http://detentionaction.org.uk/aboutus

Detention Action, 2014, Written evidence to the parliamentary inquiry into the use of immigration detention in the UK, hosted by the APPG on Refugees and the APPG on Migration, Detention

Action https://detentioninquiry.files.wordpress.com/2015/02/detention-action-1.pdf

Elgot, J, and Taylor, M, 2015, Calais crisis: Cameron condemned for 'dehumanising' description of migrants, Guardian, http://www.theguardian.com/uknews/2015/jul/30/david-cameron-migrant-swarm-language-condemned

Espadas, M.A, Aboussi, M, and Lozano, E.R, 2013, Associations of immigrants in the third sector in Andalucia: governance and networking issues, Voluntas 24, 2, 441-460.

Flynn, D, 2016, The refugee crisis: a crisis of policy rather than refugees. Migrants' Rights Network, $\quad$ http://www.migrantsrights.org.uk/blog/2016/02/refugee-crisis-crisispolicy-rather-refugees 
Foucault, M, 2002, Archaeology of Knowledge, London: Routledge.

Garkisch, M, Heidingsfelder, J, and Beckmann, M, 2017, Third sector organisations and migration: a systematic literature review on the contribution of third sector organisations in view of flight, migration and refugee crises, Voluntas, 28, 5, 1839-1880.

Gibney, M, 2004, The Ethics and Politics of Asylum: Liberal Democracy and the Response to Refugees, Cambridge, Cambridge University Press.

Gower, M, and Politowski, B, 2016, Syrian refugees and the UK response, House of Commons Library,

http://researchbriefings.parliament.uk/ResearchBriefing/Summary/SN06805\#fullrep

$\underline{\text { ort }}$

Gray, E, and Statham, P, 2005, Becoming European? The transformation of the British pro-migrant NGO sector in response to Europeanisation, Journal of Common Market Studies, 43, 4, 877-898.

Grice, A, 2015, Mediterranean migrant crisis: Britain under EU pressure to open doors to African refugees, The Independent, http://www.independent.co.uk/news/uk/politics/mediterranean-migrant-crisisbritain-under-eu-pressure-to-open-doors-to-african-refugees-10346184.html.

Hajer, M, 1993, Discourse coalitions and the institutionalisation of practice: the case of acid rain in Britain, In F. Fischer, and J. Forester, eds., The Argumentative Turn in Policy Analysis and Planning, Durham: Durham University Press.

Johnson, H, 2015, These fine lines: locating noncitizenship in political protest in Europe, Citizenship Studies, 19, 8, 951-965.

Joint Council for the Welfare of Immigrants, 2015a, In the migration debate, words matter, Joint Council for the Welfare of Immigrants, https://www.jcwi.org.uk/blog/2015/12/23/migration-debate-words-matter

Jones, M.D, and McBeth, M.K, 2010, A narrative policy framework: clear enough to be wrong?, Policy Studies Journal, 38, 2, 329-353.

Kaye, R, 1994, Defining the agenda: British refugee policy and the role of parties, Journal of Refugee Studies, 7 (2/3), 144-159.

Kim, N.H, (2009) Framing multiple others and international norms: the migrant worker advocacy movements and Korean national identity reconstruction, Nations and Nationalism, 15, 4, 678-695.

Lentin, R, and Moreo, E, 2012, Migrant Activism and Integration From Below in Ireland. Basingstoke, Palgrave Macmillan.Long, K, 2013, When refugees stopped being migrants: movement, labour and humanitarian protection, Migration Studies, 1, 1, 4-26.

Lowndes, V, and Madziva, R, 2016 'When I look at this van, it's not only a van': symbolic objects in the policing of migration, Critical Social Policy, 36, 4, 672-692. 
Mayblin, L, 2016, Complexity reduction and political consensus: asylum seekers, the right to work, and the 'pull factor' thesis in the United Kingdom, British Journal of International Relations, 18, 4, 812-828.

McGhee, D, Bennett, C, and Walker, S, The combination of 'insider' and 'outsider' strategies in VSO-government partnerships: the relationship between Refugee Action and the Home Office in the UK, Voluntary Sector Review, 7, 1, 27-46.

Migrants' Rights Network, 2016, Who are we, Migrants' Rights Network, http://www.migrantsrights.org.uk/about

Migration Watch, 2016, About Us, Migration Watch,

https://www.migrationwatchuk.org/about-us

Monforte, P, 2016, The border as a space of contention: the spatial strategies of protest against border controls in Europe, Citizenship Studies, 30, 3-4, 411-426.

Morris, N, 2015, Calais crisis: Theresa May criticised over pledge to help French deport migrants to Africa, Independent, http://www.independent.co.uk/news/uk/politics/calais-crisis-theresa-may-criticisedover-pledge-to-help-french-deport-migrants-to-africa-10425391.html

Mulvey, G, 2010, When policy creates politics: the problematizing of immigration and the consequences for refugee integration in the UK, Journal of Refugee Studies, 23, 4, 437-462.

Marquez, LMM, 2016, The relevance of organisational structure to NGOs' approaches to the policy process, Voluntas, 27, 1, 465-486.Najan, A, 2003, The four-C's of third sectorgovernment relations. Nonprofit Leadership and Management, 10, 4, 375-396.

Newman, J, and Clarke, J, 2008, Publics, Politics and Power: Remaking the Public in Public Services, London, Sage.

Pauly, R, de Rynck, F, and Verschuere, B, 2016, The relationship between government and civil society: a neo-Gramscian framework for analysis, European Group for Public Administration, Proceedings.

Phillips, R, 2002, The role of non-profit advocacy organisations in Australian democracy and policy governance, Voluntas, 17, 1, 57-73.

Prince, R, 2010, Policy transfer as policy assemblage: making policy for the creative industries in New Zealand, Environment and Planning A, 42, 1, 5-22.

Refugee Council, 2015a, A protection-based response to the crisis in the Mediterranean, Refugee Council Briefing, July 2015, https://www.refugeecouncil.org.uk/assets/0003/5306/Briefing - a protectionbased response to crisis in Med July 2015.pdf

Refugee Council, 2015b, Government consults on plans set to leave families on the streets, Refugee Council, http://www.refugeecouncil.org.uk/latest/news/4393 government consults on plans s et to leave families on the streets 
Refugee Council, 2015c, Detention is devastating, Refugee Council, http://www.refugeecouncil.org.uk/latest/blogs/4362 detention is devastating

Refugee Council, 2015d, The Refugee Council submission to the Home Affairs Select Committee inquiry into the European migration crisis, Refugee Council, https://www.refugeecouncil.org.uk/assets/0003/6225/Refugee Council submission t o HASC inquiry - European migration crisis.pdf.

Refugee Council, 2016, UK refuses to join plans to share responsibility for asylum seekers in Europe. Refugee Council,

https://www.refugeecouncil.org.uk/latest/news/4623 uk refuses to join plans to sha re responsibility for asylum seekers in europe

Ricoeur, P. 1984, Time and Narrative, Chicago, University of Chicago Press.

Right to Remain, 2015a, Whose 'side' are you on? A government threatened by solidarity, Right to Remain, http://www.righttoremain.org.uk/blog/whose-side-are-you-on-agovernment-threatened-by-solidarity/

Right to Remain, 2015b, Legal aid cuts deny thousands of vulnerable children justice, Right to Remain, http://www.righttoremain.org.uk/blog/legal-aid-cuts-denythousands-of-vulnerable-children-justice/

Roe, E, 1994, Narrative Policy Analysis: Theory and Practice, Durham, Duke University Press.

Sales, R, 2002, The deserving and the undeserving? Refugees, asylum and welfare in Britain, Critical Social Policy, 22, 3, 456-478.

Segalov, M, 2015, Calais migrant crisis: public figures tell us what they think should be done about the developing emergency; can the current situation continue?, Independent, http://www.independent.co.uk/news/uk/home-news/calais-migrant-crisis-publicfigures-tell-us-what-they-think-should-be-done-about-the-developing-10435351.html

Shariatmadari, D, 2015, Swarms, floods and marauders: the toxic metaphors of the migration debate,

Guardian, https://www.theguardian.com/commentisfree/2015/aug/10/migration-debatemetaphors-swarms-floods-marauders-migrants.

Sharma, A, 2008, Logics of Empowerment, Minnesota, University of Minnesota Press.

Singer, D, 2015, So what's new, Theresa May?, Asylum Aid, http://www.asylumaid.org.uk/so-whats-new-theresa-may/

Somerville, W, Immigration Under New Labour, Bristol, Policy Press.

Somerville, W, and Wallace Goodman, S, 2010, The role of networks in the development of UK migration policy, Political Studies, 58, 5, 951-970.

Statham, P, and Geddes, A, 2006, Elites and the 'organised public': who drives British immigration politics and in which direction?, West European Politics, 29, 2, 248-269. 
Stone, D, 2002, Policy Paradox: The Art of Political Decision-Making, New York, WW Norton.

Taylor, A, 2015, Is it time to ditch the word 'migrant'?, Washington Post, https://www.washingtonpost.com/news/worldviews/wp/2015/08/24/is-it-time-toditch-the-word-migrant/.

Taylor, M, and Warburton, D, 2003, Legitimacy and the role of UK third sector organisations in the policy process, Voluntas, 14, 3, 321-338.

Troup Buchanan, R, 2015, David Cameron description of migrant 'swarm' condemned as 'irresponsible' and 'extremely inflamatory' by human rights groups, Independent, http://www.independent.co.uk/news/world/europe/calais-crisis-live-david-cameronsays-swarm-of-illegal-migrants-will-not-be-offered-safe-haven-10426083.html

UNHCR, 2016, Syria regional refugee response, United Nations High Commissioner for Refugees, http://data.unhcr.org/syrianrefugees/regional.php

Wagenaar, H, 2011, Meaning in Action: Interpretation and Dialogue in Policy Analysis, London, Routledge.

Women for Refugee Women, 2014, Evidence for the parliamentary inquiry into detention, Detention Inquiry, https://detentioninquiry.files.wordpress.com/2015/02/women-forrefugee-women1.pdf

Women for Refugee Women, 2016, Pregnant women behind bars: a briefing on the detention of pregnant women in the UK, Women for Refugee Women, http://www.refugeewomen.co.uk/2016/wp-content/uploads/2016/03/WRWbriefing-detention-of-pregnant-women.pdf.

Zetter, R, and Pearl, M, 2000, The minority within the minority: refugee community-based organisations in the UK and the impact of restrictionism on asylum seekers, Journal of Ethnic and Migration Studies, 26, 4, 675-697. 


\begin{tabular}{|l|l|l|}
\hline Name & Size & Primary focus of work \\
\hline Refugee Council (RC) & Large & Refugees and asylum \\
\hline Migrants' Rights Network (MRN) & Medium & General migration \\
\hline Asylum Aid (AA) & Medium & Refugees and asylum \\
\hline $\begin{array}{l}\text { Joint Council for the Welfare of } \\
\text { Immigrants (JCWI) }\end{array}$ & Medium & General migration \\
\hline Right to Remain (RR) & Small & Deportation \\
\hline Detention Action (DA) & Small & Detention \\
\hline Women for Refugee Women (WfRW) & Small & Women, refugees and asylum \\
\hline
\end{tabular}

Table 1: Case Study Organisations

\begin{tabular}{|l|l|l|l|l|l|l|l|}
\hline & $\begin{array}{l}\text { Mission } \\
\text { statement }\end{array}$ & $\begin{array}{l}\text { Annual } \\
\text { report }\end{array}$ & $\begin{array}{l}\text { Policy } \\
\text { report }\end{array}$ & $\begin{array}{l}\text { Policy } \\
\text { inquiry }\end{array}$ & Blog & Newspaper & Hansard \\
\hline RC & Y & Y & 23 & 4 & 22 & 86 & 4 \\
\hline MRN & Y & Y & 4 & 0 & 67 & 18 & 1 \\
\hline JCWI & Y & Y & 11 & 0 & 22 & 9 & 2 \\
\hline AA & Y & Y & 2 & 0 & 8 & 4 & 0 \\
\hline WfRW & Y & Y & 0 & 1 & 7 & 10 & 3 \\
\hline DA & Y & Y & 3 & 1 & 9 & 3 & 5 \\
\hline RR & Y & N & 0 & 0 & 21 & 0 & 0 \\
\hline
\end{tabular}

Table 2: Breakdown of Dataset

\begin{tabular}{|c|c|c|c|}
\hline & Narratives & Modes of expertise & Positioning \\
\hline \multirow[t]{3}{*}{ Conformity } & Deservingness & \multirow{3}{*}{$\begin{array}{l}\text { Home Office data } \\
\text { interpretation }\end{array}$} & \multirow[t]{5}{*}{ Policy expert } \\
\hline & Civil liberties & & \\
\hline & Vulnerable families & & \\
\hline \multirow[t]{3}{*}{ Contestation } & $\begin{array}{l}\text { The character of the } \\
\text { crisis }\end{array}$ & Primary research & \\
\hline & $\begin{array}{l}\text { Dehumanising } \\
\text { refugees }\end{array}$ & $\begin{array}{l}\text { International } \\
\text { comparative }\end{array}$ & \\
\hline & Policy solutions & $\begin{array}{l}\text { First-hand testimony of } \\
\text { refugees }\end{array}$ & $\begin{array}{c}\text { Facilitator of } \\
\text { knowledge transfer }\end{array}$ \\
\hline
\end{tabular}

Table 3: The Narrative Assemblage of CSO Interventions into Refugee and Asylum Policy in the UK

i See Bloom (2014). 
ii Anti-migrant civil society actors have also gained significant influence in the UK. For example, Migration Watch positions itself as a 'non-political think tank' and is a significant anti-migration policy actor (Migration Watch, 2016).

iii The UK government implemented the 'Syrian Vulnerable Person Resettlement Programme' in 2014.. This scheme was extended in September 2015, with plans to admit 20,000 refugees from Syria over five years (Gower and Politowski 2016). 